
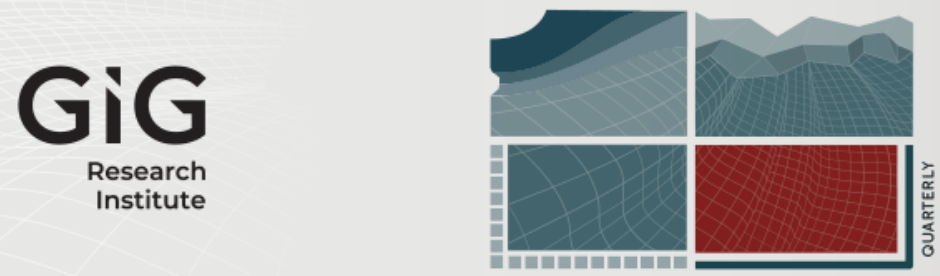

JOURNAL

OF

SUSTAINABLE

MINING

Volume 19 | Issue 2

Article 5

2020

\title{
Recovery and repurposing of thermal resources in the mining and mineral processing industry
}

Author(s) ORCID Identifier:

Shannon H. McLean (iD) 0000-0001-9900-640X

Corey Laamanen (iD) 0000-0002-1321-0491

John A. Scott (iD) 0000-0002-2559-0188

Follow this and additional works at: https://jsm.gig.eu/journal-of-sustainable-mining

Part of the Explosives Engineering Commons, Oil, Gas, and Energy Commons, and the Sustainability

\section{Commons}

\section{Recommended Citation}

McLean, Shannon H.; Chenier, Jeffrey; Muinonen, Sari; Laamanen, Corey A.; and Scott, John A. (2020) "Recovery and repurposing of thermal resources in the mining and mineral processing industry," Journal of Sustainable Mining: Vol. 19 : Iss. 2 , Article 5.

Available at: https://doi.org/10.46873/2300-3960.1010

This Review is brought to you for free and open access by Journal of Sustainable Mining. It has been accepted for inclusion in Journal of Sustainable Mining by an authorized editor of Journal of Sustainable Mining. 


\title{
Recovery and repurposing of thermal resources in the mining and mineral processing industry
}

\author{
Abstract \\ The consumption of energy contributes significantly to the overall cost of operations and the \\ environmental impact of the mining and mineral processing industry. However, despite a few notable \\ exceptions, most of the resulting waste heat produced is dissipated, without recovery, into the \\ environment. There is also a lot of stored heat in mine water which can be tapped into long after a mine \\ has closed. There is, therefore, significant opportunity to improve the industry's sustainability through \\ increasing the amount of waste heat recovered and repurposed.

\section{Keywords} \\ Energy recovery; Mining; Environmental sustainability; Heat pumps; Waste heat

\section{Creative Commons License} \\ (c) (i)
}

This work is licensed under a Creative Commons Attribution 4.0 License.

\section{Authors}

Shannon H. McLean, Jeffrey Chenier, Sari Muinonen, Corey A. Laamanen, and John A. Scott 


\title{
Recovery and repurposing of thermal resources in the mining and mineral processing industry
}

\author{
Shannon H. McLean ${ }^{a}$, Jeffrey Chenier ${ }^{b}$, Sari Muinonen ${ }^{b}$, \\ Corey A. Laamanen ${ }^{a}$, John A. Scott ${ }^{a, *}$ \\ a School of Engineering, Laurentian University, 935 Ramsey Lake Road, Sudbury, ON, Canada \\ b Sudbury Integrated Nickel Operations (a Glencore Company), Sudbury, ON, Canada
}

\begin{abstract}
The consumption of energy contributes significantly to the overall cost of operations and the environmental impact of the mining and mineral processing industry. However, despite a few notable exceptions, most of the resulting waste heat produced is dissipated, without recovery, into the environment. There is also a lot of stored heat in mine water which can be tapped into long after a mine has closed. There is, therefore, significant opportunity to improve the industry's sustainability through increasing the amount of waste heat recovered and repurposed.
\end{abstract}

Keywords: energy recovery, mining, environmental sustainability, heat pumps, waste heat

\section{Introduction}

I ndustry, as a whole, accounts for around one third of the world's total energy consumption and about $36 \%$ of $\mathrm{CO} 2$ emissions [1]. The mining industry is responsible for $4-7 \%$ of the total energy consumption [2] and despite an increase in the use of renewable energy, there is still a heavy reliance on fossil fuels [3]. In Canada, for example, $\mathrm{CO} 2$ emissions released from the mining industry grew from about $22.5 \mathrm{Mt}$ in 1990 to $74.5 \mathrm{Mt}$ in 2016 [4]. Energy preservation and management can be accomplished by cutting down on high energy consuming equipment and implementing more efficient technologies [5]. Strides are also being made towards improving energy efficiency through the recovery and reuse of what is otherwise waste heat - the so called 'first fuel' option [6].

It has been estimated that of the total amount of energy consumed in industrial processes, up to $70 \%$ is lost as waste heat [7], i.e. thermal energy that is not captured and is rejected into the environment [8].

Energy usage in mining and mineral processing operations is dominated by a few major processes, including ventilation pumping, comminution and smelting, all of which offer the potential for energy recovery. Mine ventilation, for example, can account for up to $40 \%$ of a deep underground mine's total electricity consumption [9], an essential operation to bring fresh air underground and keep areas cool. The smelting process is an extractive metallurgy technique and involves the application of heat to extract metals from their ores [10]. Pumping, particularly in large mining sites, uses significant quantities of energy, which is on average $25 \%-32 \%$ of total motor energy [11]. Comminution (crushing and grinding) reduces the size of the ore to allow further processing to take place. Comminution contributes to approximately $40 \%$ of the total energy used in mineral processing [12]. Much of the energy consumed by grinding practices is lost as heat to the ore, resulting in an energy efficiency process of only $1 \%$ [11].

Operations, such as process cooling water and offgasses, expel considerable amounts of unrecovered energy in the form of waste heat $[3,8]$. Underground

Received 13 November 2019; revised 24 February 2020; accepted 25 February 2020.

Available online 5 October 2020.

* Corresponding author.

E-mail address: jascott@laurentian.ca (J.A. Scott). 
mining, for example, has several energy intensive stages, including hauling, ventilation, pumping and dewatering [11], with little or none of the generated heat captured. In mineral processing, $20-50 \%$ of the primary energy is lost as waste heat [13]; pp. 47-52). It is proposed, therefore, that the industry could significantly benefit from the recovery and repurposing of its waste to offset primary energy purchases in order to enhance overall sustainability.

Whilst advancement in technologies and the improvement of equipment to reach higher efficiencies can limit the release of waste heat and improve industrial sustainable development, studies have shown that one of the most effective ways to improve energy efficiency without the use of major equipment or facility alterations is through waste heat recovery [14]. The recycled energy can, for example, be used to power auxiliary equipment, generate steam, or deliver space heating and cooling [14].

In general, waste heat can be classified as either low or high-grade. High-grade waste heat is at a temperatures greater than $100{ }^{\circ} \mathrm{C}$, and is often used to generate steam or it is recycled directly back into a process [15]. High-grade waste heat can also be captured and used for power generation by driving heat engines, such as those that use the Rankine cycle [8]. Low-grade waste heat is, therefore, typically considered to have a temperature below $100^{\circ} \mathrm{C}$. Temperatures between 70 and $100^{\circ} \mathrm{C}$ may be upgraded by adding energy to raise the temperature to allow for beneficial repurposing, such as steam generation $[16,17]$. However, at temperatures below $70^{\circ} \mathrm{C}$, currently little of this lowgrade waste heat is recovered in the mining industry.

Table 1 summarizes methods of recovering various waste heat sources present in the mining and mineral processing industry, as well as the potential applications for the recovered energy. This review focuses on these various sources of waste heat and the recovery practices and technologies that could be implemented.

\section{Underground mining operations}

Mining is classified into surface and underground operations, depending on the location, size, depth and grade of the deposit [11]. Surface mining operations do not utilize heating, ventilation and air conditioning (HVAC), which accounts for over $25 \%$ of underground mine energy consumption [37]. Underground mining also requires more energy to cope with extended requirements for hauling and dewatering [11]. As a consequence, the focus here is on heat recovery from underground mines.

\subsection{Mine water}

The need for dewatering in both operating and closed mines presents a promising opportunity for geothermal energy recovery. Mine dewatering usually consists of pumping water from a series of

Table 1. Summary of waste heat recovery methods and potential applications.

\begin{tabular}{|c|c|c|c|c|}
\hline Waste Heat Source & $\begin{array}{l}\text { Heat Recovered } \\
\text { (MW) }\end{array}$ & Recovery Method & Potential Application & Stage of Recovery Method \\
\hline $\begin{array}{l}\text { Mine ventilation } \\
\text { exhaust }\end{array}$ & 9-11 [18,19] & $\begin{array}{l}\text { Direct spray recovery with heat } \\
\text { pump [19] } \\
\text { Heat exchangers [21] }\end{array}$ & $\begin{array}{l}\text { Ventilation preheating } \\
\text { [20] } \\
\text { Space heating }[21]\end{array}$ & $\begin{array}{l}\text { Potential recovery } \\
\text { methodmethod }\end{array}$ \\
\hline Mine dewatering & $1-5[22]$ & Heat pumps [23] & Space heating $[23,24]$ & Implemented in industry \\
\hline $\begin{array}{l}\text { Electric Arc } \\
\text { Furnace } \\
\text { cooling water }\end{array}$ & $10-60[25]$ & $\begin{array}{l}\text { Heat exchangers [26] } \\
\text { Steam generators [26] }\end{array}$ & $\begin{array}{l}\text { Electricity generation [27] } \\
\text { Steam [27] }\end{array}$ & Potential recovery method \\
\hline Off-gas & $60[28]$ & $\begin{array}{l}\text { Organic Rankine Cycle [29] } \\
\text { Bubbled-in off-gas [30] }\end{array}$ & $\begin{array}{l}\text { Electricity generation [29] } \\
\text { Microalgae cultivation [30] }\end{array}$ & Implemented in industry \\
\hline Slag recovery & $9-20[31,32]$ & $\begin{array}{l}\text { Mechanical crushing with heat } \\
\text { pump recovery [33] } \\
\text { Centrifugal and air blast } \\
\text { granulation using fluidized bed } \\
\text { recovery [33] } \\
\text { Packed-bed heat exchanger [32] }\end{array}$ & $\begin{array}{l}\text { Preheating air of ore } \\
\text { dryers [34] } \\
\text { Reheating boiler feed } \\
\text { water [34] } \\
\text { Electricity or steam } \\
\text { generation [35] } \\
\text { Combustion air } \\
\text { preheating [35] }\end{array}$ & Potential recovery method \\
\hline $\begin{array}{r}\text { Smelter process } \\
\text { cooling water }\end{array}$ & $40[6]$ & Heat pumps [6] & $\begin{array}{l}\text { Space heating [6] } \\
\text { Steam production [36] }\end{array}$ & Potential recovery method \\
\hline
\end{tabular}




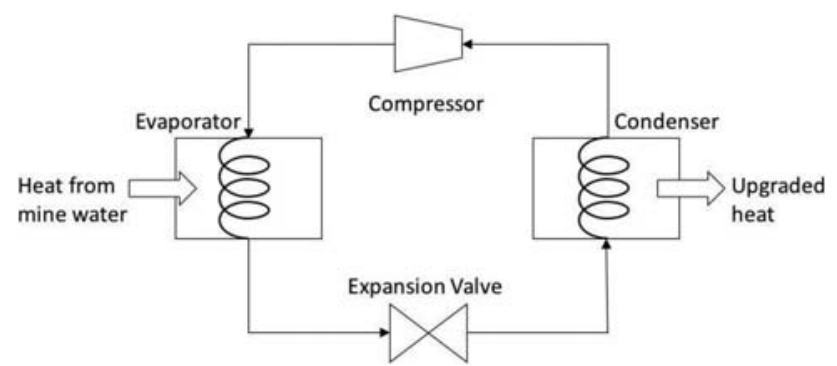

Fig. 1. Heat pump principle in mine dewatering application (adapted from [38]).

wells within the mine to the surface. Dewatering is important, as water levels must be continuously managed to ensure the stability of mine walls and to prevent flooding. Unwanted water can enter a mine from surface accumulations, aquifers, bed separation cavities, solution cavities and old mine workings [23]. Extracting heat from deep underground is beneficial, due to geothermal gradients and large water-rock interfaces resulting in a transfer of heat to the water [22]. The application of geothermal heat pumps can allow for the low-grade thermal energy from warm mine water to be used in a variety of space heating and cooling applications [24].

Heat pumps use external energy (typically electricity) to upgrade heat to a higher temperature. In a compression heat pump, low temperature heat is absorbed in an evaporator and the vapor is then compressed, resulting in the rejection of heat at an elevated temperature in a condenser, illustrated in Fig. 1. Heat is recovered from the condensed fluid, which in turn is expanded and the cycle repeats [5]. The upgraded temperature can be useful for repurposing in applications.

However, a major limitation of the application of the recovered heat is the temperature rise provided by a heat pump, which is typically $25^{\circ} \mathrm{C}$ or less [5]. This is seldom exceeded, since compressors with high ejection pressures, which therefore generate higher temperatures, will have increased payback periods due to much higher capital and operating costs [5]. Therefore, with low-grade heat, output temperatures greater than $110^{\circ} \mathrm{C}$ are rarely achieved, making the heat recovered by heat pumps unsuitable for many industrial process applications [17].

In an effort to overcome this limitation, chemical heat pump technologies are emerging for the more effective extraction and repurposing of thermal energy. They are driven by reversible chemical reactions and are an environmentally low impact method [39]. The capacity of the system for storage along with the ability to efficiently upgrade thermal energy and deliver it at high temperatures of more than $200^{\circ} \mathrm{C}$ makes it a beneficial solution for lowgrade heat recovery [40].

Additionally, after an underground mine is closed, continuous dewatering practices are usually scaled down or ceased, and water levels may rise until the mine is flooded. As a consequence, abandoned mines can still provide a resource for geothermal energy recovery [40,41]. It has been estimated that there are over one million abandoned mines worldwide, with approximately $3000 \mathrm{MW}$ of heat energy remaining untapped in the water within the flooded coalfields of Europe alone [22].

Pumping water from abandoned mines may require a significant amount of electricity, and may be too costly, but there are sites where gravity assists in the discharge of water, or pumping is already required for the maintenance of abandoned mines [22]. In some locations, pumping and treatment facilities are installed to control water levels, as well as treat the water to the extent necessary to make it safe for release to the environment. The treatment technology depends on the characteristics of the mine water, but may include chemical precipitation, membrane applications, and/or biological treatment [42]. As the energy demand of a treatment facility may be very high, particularly due to large pumping requirements, it presents an opportunity for a heat recovery application to off-set costs [22].

Heat pump technology is currently used in many low-grade heat recovery systems for mines. For example, in Great Britain, the escape of contaminated water into the environment from abandoned coal mines is being addressed by the Coal Authority and they have installed 64 treatment systems [22]. A study was undertaken that analyzed 21 of these treatment sites and compared electrical power consumption and thermal power potential [22]. The total low-grade thermal energy of all the mine waters considered was 47.5 MW. Many of the mines that required large power consuming treatment facilities also provided the greatest heat resources due to deep mine waters. For example, for a mine in Durham, England with groundwater temperatures of around $15^{\circ} \mathrm{C}$, it was found that a temperature drop of $4{ }^{\circ} \mathrm{C}$ could achieve $4.85 \mathrm{MW}$ of recoverable energy. Whilst at another mine in England, a temperature drop of $4{ }^{\circ} \mathrm{C}$ could achieve $806 \mathrm{kWt}$ of recoverable energy. A gravity fed treatment system with water temperatures around $14{ }^{\circ} \mathrm{C}$ at Morlais in South Wales was found to offer around 2.90 MW of recoverable thermal energy by reducing the temperature of its water flow by $4{ }^{\circ} \mathrm{C}$ [22].

It has been proposed that the application of heat pumps would be a feasible option to capture this 
otherwise wasted heat at high efficiencies. In Shettleston, Scotland, a system was installed to recover energy from water in flooded coal mines at a depth of $100 \mathrm{~m}$ [23]. Two heat pumps were used to provide space heating by heating the water to $55^{\circ} \mathrm{C}$ before storing it in a tank for subsequent distribution to 16 nearby houses. In Heerlen, Netherlands, a geothermal district heating system has been implemented by repurposing thermal energy from several mine shafts in a flooded abandoned coal mine. The system, which provides district heating and cooling to over 350 homes and businesses, was achieved by drilling five wells $700 \mathrm{~m}$ deep around the town in order to access underground mine shafts [43]. The wells are able to pump nearly $80 \mathrm{~m}^{3}$ of water per hour at temperatures between $15^{\circ} \mathrm{C}$ and $30^{\circ} \mathrm{C}$ [44], and a heat pump is used at the surface to extract and generate heat at an average of $28^{\circ} \mathrm{C}$ [43].

A heat recovery project in Nova Scotia, Canada was carried out by a plastic packaging manufacturer. It involved the instalment of ground source heat pumps to take advantage of otherwise wasted heat in flood water from abandoned coal mines [45]. At a water temperature of $18^{\circ} \mathrm{C}$, an initial projection found energy savings as high as $70 \%$ could be achieved [46]. The water was pumped from $140 \mathrm{~m}$ below the surface, extracting heat and lowering the mine water temperature to $13{ }^{\circ} \mathrm{C}$. Eleven heat pumps were installed to provide hot water heating at the plastics plant, at a rated capacity of $985 \mathrm{kWh} /$ day [46]. The capital cost to implement the heat pump system was $\$ 110,000$, as opposed to $\$ 70,000$ for the alternative propane heating system [46]. However, operating costs of the heat pump system provided annual savings of approximately $\$ 45,000$ [47].

A geothermal heat recovery system was implemented in the city of Asturias, Spain, at an abandoned coal mine near the University of Oviedo [48]. The heat from the flooded mine water is recovered using four geothermal heat pumps to provide water heating at a temperature of $46^{\circ} \mathrm{C}$ to two of the university buildings, as well as to a nearby hospital. At an average water flow of $215 \mathrm{~m}^{3} / \mathrm{h}$, the recovery system reduces the temperature of the mine water from $23^{\circ} \mathrm{C}$ to $13.9^{\circ} \mathrm{C}$, allowing for a total annual energy saving of approximately $73 \%$ and an annual $\mathrm{CO}_{2}$ reduction of $39 \%$.

Other types of mines can also be considered, such as the abandoned Wheal Jane tin mine in Cornwall, England, which after flooding began to leak water into the environment. A treatment system was installed to control mine water discharges and involved pumping water from the shaft and treating it with lime. When the treatment facility was eventually discontinued in 1992, the mine had released $50,000 \mathrm{~m}^{3}$ of water with an average metal concentration of $3500 \mathrm{mg} / \mathrm{L}$ to the surrounding environment [23]. It has been suggested that this would be a prime opportunity to install a heat recovery system and continue long-term monitoring and treatment of the mine water [23]. A copper, zinc and sulphur mine in Norway that closed in 1941 established a heat recovery system from the water of the abandoned mine [49]. A heat pump was installed to provide space heating for an underground cavern which is used by the community for various events.

Geothermal heat pumps typically have high initial investment costs due to connections underground, including drilling, piping and excavation [50], costs that can largely be avoided if utilizing an abandoned flooded mine. Con mine, an abandoned gold mine in Yellowknife, Canada is a prospective geothermal heat source for the city based on a preliminary study on the potential to recover low-grade heat for space heating [51]. Of the total energy consumed by the community, approximately $70 \%$ is for space heating, resulting in about 277,000 tons of greenhouse gas emissions annually [52]. The study focused on possible technologies to recover heat, as well as approximate costs and payback periods using the example of a $300 \mathrm{~kW}$ heat demand [52]. Heat pumps were found to be a potential solution for heat recovery from mine water $400 \mathrm{~m}$ below the surface [51]. The temperature would be increased from $35^{\circ} \mathrm{C}$ to about $45^{\circ} \mathrm{C}$, with a total power requirement of $90 \mathrm{~kW}$ [52]. The net annual savings were projected to be $\$ 95,000$ for the project, with a payback period of less than 8 years [52]. The study demonstrates the economic feasibility of heat pumps over time, as they typically have a higher initial capital cost compared to other heating systems, but lower operating costs.

\subsection{Mine ventilation exhaust}

Through heat transfer from the host rock, geothermal heat is a large contributor to the air temperature of deep mines and the necessary air conditioning and ventilation requirements create a high-energy demand. Exhausted mine ventilation air temperature is typically around $30^{\circ} \mathrm{C}$, with the relative humidity being about $90 \%$ [19], and in many cases this heat is released to the atmosphere at temperatures higher than ambient [21]. A ventilations system's wet airflow carries, therefore, a significant quantity of latent heat that could be available for energy recovery and reuse [19]. Waste heat can be extracted from this exhaust air using a medium like water or glycol and then used for 
underground ventilation inflow heating or directed to an alternative application, such as space heating of nearby buildings [21].

For mines located in cold climates, heating the air intake can also contribute significantly to the overall cost of operation. The $700 \mathrm{~m}$ deep Kylylahti copper mine in Finland, to prevent shafts and equipment from freezing, requires heating the supply ventilation air to approximately $3{ }^{\circ} \mathrm{C}$ during months when ambient temperature ranges between $0^{\circ} \mathrm{C}$ and $-15^{\circ} \mathrm{C}$ [20]. The heating system is currently achieved with two gas burners, but with the supply airshaft and the return airshaft only $30 \mathrm{~m}$ apart, this provides an opportunity to exchange heat between the two airflows.

A laboratory experiment in China analyzed the combination of a direct spray recovery unit with a heat pump system for the extraction of low-grade energy from air mine exhaust [19]. A multi-stage reverse spray heat exchanger was used, where water is sprayed in the opposite direction of the airflow in multiple stages to improve heat transfer efficiency. This enabled the temperature of the spray water to increase from $7{ }^{\circ} \mathrm{C}$ to about $15^{\circ} \mathrm{C}$. A heat pump was subsequently used to extract this heat, with the cooled water returned back to the spray tower. The average exhaust ventilation air temperature and humidity at the surface during cold months are parameters that need to be taken into account to calculate heat recovery potential [21]. A heat pump is an efficient option, since the temperature and humidity of the exhaust air remains fairly constant.

In one of the experiments, $3.47 \mathrm{~kg} / \mathrm{s}$ of cold water recovered heat at $119 \mathrm{~kJ} / \mathrm{s}$ from $3.52 \mathrm{~kg} / \mathrm{s}$ of air when the spray coefficient was 0.9. The results showed that heat exchange efficiency could reach over $85 \%$. This investigation led to the prediction that application in a mine with an air flow rate of about $7.2 \times 10^{5} \mathrm{~m}^{3} / \mathrm{h}$ and using $759 \mathrm{~m}^{3} / \mathrm{h}$ of cold water could recover about $11 \mathrm{MW}$.

\section{Mineral processing off-gas}

\subsection{Electric arc furnaces}

The production of steel is often accomplished with the use of an electric arc furnace (EAF) [53], technology, which in comparison to a blast furnace, produces less waste and has a lower energy consumption per ton of steel [54]. Electric arc furnaces consume electrical energy and fuels, such as natural gas, to melt and convert solid materials, e.g. iron scraps, into molten steel, which is then further refined to produce high-grade steel [55]. Nevertheless, the iron and steel industry is one of the largest polluters of the industrial sector [26], contributing approximately $4 \%$ of the total global greenhouse gas emissions [54].

The amount of energy required by an EAF to melt scrap iron is $350-370 \mathrm{kWh} /$ tsteel [55] and this releases large amounts of waste heat in an off -gas that is typically around $1250{ }^{\circ} \mathrm{C}$ and with flow rates of up to $150,000 \mathrm{Nm}^{3} / \mathrm{h}$ [27]. It is estimated that up to $50 \%$ of all energy losses and nearly $30 \%$ of the energy input is lost in the off-gas from EAFs [53]. Heat recovery from EAFs in the steel industry could, therefore, significantly improve process efficiency, and reduce costs and greenhouse gas emissions.

The Organic Rankine Cycle (ORC) is a piece of technology that can be used to recover high-grade heat from an EAF for use in power generation. In 2013, The ORC production company Turboden successfully implemented a heat recovery system from the off-gas of a $133 \mathrm{t} / \mathrm{h}$ EAF used in an iron and steel manufacturing plant in Riesa, Germany [29]. From an off-gas temperature of $1600^{\circ} \mathrm{C}$, the ORC unit used in the design allowed for $3 \mathrm{MW}$ of electrical output, resulting in a payback period of approximately five years.

Off-gases from EAFs must be cooled before they can enter the de-dusting (dust collection) stage. Typically, they are cooled inside a water-cooled hot gas duct to reduce the temperature to the maximum allowable for the dust collectors, about $600{ }^{\circ} \mathrm{C}$, with the removed heat dissipated to the environment [26]. This has been, therefore, an area of particular interest for heat recovery and application research, as the dissipated low-grade energy could be used by a number of process technologies within the steel production plant. For example, waste heat recovered from an EAF could be used for electric energy generation, steam production, or scrap metal preheating before the melting process [27].

Energy can be recovered and repurposed at the gas cooling phase through steam generation for use in processes such as shop and office heating, as well as in mills for jacket heating of pickling tanks and fuel oil lines [56]. Steam can also be used for electricity generation using steam turbines [57]. In steam generation, an evaporative cooling system can be installed at the de-dusting system of the EAF and steam generated as water evaporates during the cooling process [53].

A study was performed on a 145-ton EAF [53] to determine the effectiveness of an evaporative cooling system integrated in the cooling water circuit of the de-dusting system at various water pressures. It was found that when the pressure of the boiling water was at an optimal $1 \mathrm{MPa}$, the amount of steam produced from the heat discharged in the gas was 
25.3-28.8 tons per 145 ton batch, with a total exergy of 20-23 GJ.

A waste heat recovery model for steam production from a steel plant was developed in order to find optimized operating parameters [26]. In the model, waste heat was recovered from an EAF used to melt steel scrap and produce molten steel, and the recovery system included heat exchangers, steam generators and a thermocline storage tank. The offgas was to be cooled to $600^{\circ} \mathrm{C}$ from a peak temperature of $1200^{\circ} \mathrm{C}$ using cooling water. The cooling water outlet temperature was around $50^{\circ} \mathrm{C}$, but was increased to $200^{\circ} \mathrm{C}$ in the model to directly recover heat by producing saturated steam in a shell and tube steam generator. An alternative heat recovery option that utilized heat pumps to upgrade this stream temperature was also considered. The mass flow of cooling water inside the cooling system was controlled using a circulation pump to deliver a minimum mass flow of cooling water in the hot gas line and ensure efficient heat transfer. It was determined from this study that stable and continuous operation was achievable with this approach.

\subsection{Smelters}

Industrial waste heat recovery from a smelter can provide the necessary conditions required to grow and maintain microalgae year-round in cold regions [30], with the lipids they produce a potential biodiesel feedstock [58]. Due to its relatively cleanburning characteristics, biodiesel can be especially useful in underground mine applications [6,59].

However, the mass production of microalgae is traditionally not possible in temperatures that drop below $15^{\circ} \mathrm{C}$ and, therefore, it was previously found to be practical only in year-round warm climates $[30,60]$. To resolve this issue for cold climates where many mining and mineral processing operations exist, employing waste heat from a nickel smelter site to support algal growth tanks has been investigated [28]. The two major sources of waste heat identified were off-gas streams from the fluidized bed roasters and the furnace. The roaster off-gas undergoes on-site gas cooling from $680{ }^{\circ} \mathrm{C}$ to $50^{\circ} \mathrm{C}$ to enable the capture of $\mathrm{SO} 2$ through the production of sulfuric acid. Whilst the off-gas from the furnace is released at a temperature of approximately $350{ }^{\circ} \mathrm{C}$ [30]. The off-gas streams represent a combined $60 \mathrm{MW}$ of waste heat dissipated into the environment without any recovery [28].

A study modelled the impact on algal pond temperature from direct bubbled-in off-gas from the furnace and heat recovered by a heat exchanger from the roaster off-gas [30]. The results showed that significant microalgae cultivation could be achieved year-round, even when ambient air temperatures fall well below $0{ }^{\circ} \mathrm{C}$.

\section{Slag waste heat}

The slag from smelter furnaces represents a substantial amount of "stored" energy, which is lost during solidification. It is estimated that over $40 \%$ of the energy supplied to a smelter furnace remains in the slag, with 1-2 GJ of thermal energy contained within one ton $[35,61]$. Slag has potential commercial value after proper cooling and treatment $[62,63]$, and it is during this process that waste heat recovery can be achieved [64]. For example, blast-furnace slags can be used as a feedstock in the manufacturing of cement, with slag representing approximately $13 \%$ of world cement production $[65,66]$.

Traditionally, solidification was achieved through water quenching, with large volumes of water used to rapidly cool molten slags [33,67]. In this technique, molten slag at a temperature of around $1500{ }^{\circ} \mathrm{C}$ may be cooled to around $50^{\circ} \mathrm{C}$ using a high velocity water stream $[67,68]$. The water used in this process is recycled and cooled to less than $50{ }^{\circ} \mathrm{C}$, typically by using cooling towers [68]. One of the major drawbacks of this technique is the difficulty of achieving heat recovery using direct application methods, such as heat exchangers, due to the large heat loss through evaporation whilst cooling the slag $[69,70]$. In addition, low-grade heat is released from the cooling towers to the environment without being recovered [69]. However, this could provide an opportunity for the application of heat pumps to upgrade this low-grade waste heat, allowing for the implementation of a heat recovery system.

With modern slag solidification methods, heat recovery systems that allow for cooling requirements to be achieved are becoming more common. These include the production of steam or hot water for power generation and other industrial processes, or heating the air of ore dryers [71,72]. The recovered energy can also be incorporated back into the furnace process by preheating combustion air [35].

A study using both laboratory-scale and pilotscale experiments evaluated a heat recovery system using a packed bed of hot slag plates [73]. The molten slag was solidified in the shape of a plate using water-cooled rolls and then it was used in a packed slag chamber where heat exchange took place with a counter-current gas flow. The slag temperature in the pilot-scale test was around $1100^{\circ} \mathrm{C}$, and the maximum gas temperature 
measured was $716{ }^{\circ} \mathrm{C}$ [73]. From this it was determined that the heat recovery ratio relative to the total heat of the molten slag was $43 \%$ [73].

Dry solidification of slag is currently being developed as it offers the potential for an efficient solidification process whilst also providing the opportunity for heat recovery [35]. The process involves breaking up liquid slag into droplets that are passed through a dry cooling stage, where heat can be recovered as they solidify into granules [61]. Using air blast or centrifugal granulation methods in the dry cooling stage, heat is transferred from the droplets to air $[33,61,74]$. Further heat recovery can be achieved as the solid granules are further air cooled, often with a fluidized bed [35,61].

Early dry granulation techniques involved mechanical crushing with rotating drums [33] and then transferring the broken slag to a cooling chamber where heat exchange could take place with air [33]. However, processing methods such as this typically only allow for low-grade heat to be recovered, wasting a large amount of the thermal content in the slag [34]. Heat recovery from mechanical crushing could, therefore, be an opportunity to apply heat pumps to upgrade the thermal energy to a useful temperature.
New technologies are being investigated to enable recovery at higher temperatures, of which rotating cup granulation is a leading centrifugal method $[33,64]$. This involves liquid slag being poured into a high-speed rotating cup, which forms droplets that cool as they are ejected outwards. The process produces hot air, typically in the range of $200-300^{\circ} \mathrm{C}$, which is passed through an exchanger to recover the heat and can be used for combustion air preheating or to produce steam or electricity $[35,61]$. In a commercial trial carried out in Britain, it was found that $59 \%$ of the slag heat could be recovered when slag particles were cooled to $250^{\circ} \mathrm{C}$ from an initial slag temperature of around $1500^{\circ} \mathrm{C}$ $[33,61]$.

Another option is an air blast process, where the molten slag comes into contact with gas traveling at high speed and pressure, resulting in the slag breaking up into small particles [61]. This process again uses a fluidized bed to remove heat from the solid granules. A heat recovery system was adapted to a laterite nickel rotary kiln electric furnace plant in Canada, where slag was granulated using a high velocity air jet inside a waste heat boiler to produce granules [34]. The granules were cooled by radiation to water-cooled boiler walls and by convection to the granulation air. Heat application methods were

Table 2. Comparison of various slag solidification methods.

\begin{tabular}{|c|c|c|}
\hline $\begin{array}{l}\text { Slag Solidification } \\
\text { Method }\end{array}$ & Advantages & Disadvantages \\
\hline \multirow[t]{4}{*}{ Water quenching } & $\begin{array}{l}\text { Produces a glassy slag suitable for the cement } \\
\text { industry [32] }\end{array}$ & Difficult to achieve heat recovery $[69,70]$ \\
\hline & Efficient cooling of high temperature slag [75] & High water consumption [70] \\
\hline & $\begin{array}{l}\text { Reduced greenhouse gas emissions compared } \\
\text { to cement production from limestone [32] }\end{array}$ & $\begin{array}{l}\text { Air pollution (SO2 and } \mathrm{H} 2 \mathrm{~S} \text { emissions) } \\
\text { [75] }\end{array}$ \\
\hline & Suitable for large-scale applications [32] & $\begin{array}{l}\text { High energy consumption with } \\
\text { additional drying requirements [75] } \\
\text { Large particle size [70] }\end{array}$ \\
\hline \multirow[t]{2}{*}{$\begin{array}{l}\text { Mechanical crushing } \\
\text { with rotating drums }\end{array}$} & $\begin{array}{l}\text { Opportunity for low grade heat recovery using } \\
\text { heat pumps [34] }\end{array}$ & $\begin{array}{l}\text { Reduced processing capacity due to } \\
\text { slag pieces attaching to drum [70] }\end{array}$ \\
\hline & $\begin{array}{l}\text { Up to } 60 \% \text { heat recovery can be achieved [70] } \\
\text { Decreases water consumption and gas } \\
\text { emissions for minimal environmental impact } \\
\text { [35] }\end{array}$ & $\begin{array}{l}\text { Not suitable for industrial scale } \\
\text { operation [32] }\end{array}$ \\
\hline \multirow{5}{*}{$\begin{array}{l}\text { Rotating cup } \\
\text { granulation } \\
\text { centrifugal }\end{array}$} & Minimal environmental impact [32] & Still in development phase [32] \\
\hline & Small slag particle size [70] & $\begin{array}{l}\text { Not well tested for large-scale } \\
\text { applications [32] }\end{array}$ \\
\hline & Allows for high grade waste heat recovery [35] & Heat recovery process requires \\
\hline & High glassy phase [32] & fluidized bed [35] \\
\hline & High process capacity [70] & \\
\hline \multirow[t]{3}{*}{ Air blast } & Minimal environmental impact [32] & $\begin{array}{l}\text { Heat recovery process requires } \\
\text { fluidized bed [35] }\end{array}$ \\
\hline & Allows for high grade waste heat recovery [34] & $\begin{array}{l}\text { Large volume of air results in high } \\
\text { energy consumption and operating } \\
\text { costs [70] }\end{array}$ \\
\hline & High process capacity [70] & Low cooling speed [70] \\
\hline
\end{tabular}


established to integrate the recovered energy into the smelter, including preheating air at the ore dryers, reheating boiler feed water, and electricity generation. From this study, it was determined that the heat recovery system could provide up to $25-30 \%$ of the total electrical requirements of the rotary kiln electric furnace, as well as reduce $\mathrm{CO} 2$ emissions by 234,000 tons per year [34].

A dry granulation heat recovery technique was developed to recover high-grade heat from molten slag [32]. Slag droplets were formed in a dry granulator process, which were cooled to produce glassy granules at a temperature of about $900{ }^{\circ} \mathrm{C}$. These granules were transferred to a packed-bed heat exchanger to allow for heat recovery from the slag. It was found that the system could allow for approximately $80 \%$ of the heat to be recovered to produce hot air or steam at temperatures above $600^{\circ} \mathrm{C}$, which could be used in drying and preheating applications.

The challenges associated with employing various slag solidification methods are demonstrated in Table 2.

\section{Process water}

During the study of a smelter, a number of process streams in the facility were identified for lowgrade heat recovery [6]. The smelter processed mainly nickel and copper custom feeds and concentrates, with annual production of around 75,000 tons of nickel and 23,000 tons of copper. With nickel and copper bearing sulphide ores as the primary feedstock, the total waste heat rejected to the environment from the fluidized bed roaster off-gas, the furnace off-gas, the furnace cooling water, the matte granulation cooling water and the acid plant cooling water during operation was calculated to be in excess of $100 \mathrm{MW}$ [6].

The most promising streams were found to be process cooling waters from the calciner, the matte granulation process and the furnace, as these were all in the temperature range $\left(20-90^{\circ} \mathrm{C}\right)$ which is suitable for the application of heat pumps [76]. It was determined that for the beneficial application of the recovered energy, the waste heat would first need to be upgraded by heat pumps. This offered the potential to provide space heating and cooling of a nearby office building, and to replace an aging natural gas furnace with an average annual demand of $510 \mathrm{~kW}$, as well as reduce $\mathrm{CO} 2$ emissions by approximately $62 \%$ [6].

An iron and steel plant located in the Netherlands was investigated to determine the feasibility of implementing a heat recovery system using cooling water from the rolling process, where rolled steel is cooled by spraying water at a temperature of $80^{\circ} \mathrm{C}$ [36]. A preliminary study found that waste heat from the cooling water of the hot strip mill can be recovered using an absorption heat pump, which could then be applied to produce low pressure steam at $1.7-3.5$ bar and $130^{\circ} \mathrm{C}$ [36]. It was determined that emission reductions of $1.9 \mathrm{~kg} \mathrm{CO}_{2} /$ trolled steel could be achieved with the implementation of this technology [36].

\section{Conclusion}

The mining and mineral processing industry is extremely energy intensive, yet in general carries out relatively little waste heat recovery and repurposing. Many sites are located in very cold climates where recovery and repurposing on-site to supply space heating or the pre-heating of gas and liquid process streams could significantly contribute to the sustainability of the operation. Where recovery does exist, the target is generally high-grade waste heat sources in gasses or liquids with temperatures greater than $100{ }^{\circ} \mathrm{C}$, most of which is related to smelter furnaces. This high-grade heat in the exhaust gas from electric arc furnaces, for example, can be extracted for direct recovery applications, such as steam generation, electricity production, or process stream preheating. In most cases use of heat exchangers, which are well understood and widely used throughout all industries, prove to be the most appropriate recovery route. Although, over $40 \%$ of the energy supplied to a smelter furnace remains in the slag, representing substantial energy that is rarely tapped. High-grade waste heat can also be captured and used for power generation by driving heat engine technologies such as the Rankine cycle.

Significant opportunity also lies in the abundant quantities of low-grade thermal resources which are less than $100^{\circ} \mathrm{C}$. Recovered energy, again usually with heat exchangers, from process streams with temperatures between 70 and $100^{\circ} \mathrm{C}$ may be upgraded by adding energy to raise the temperature to allow for repurposing, e.g. through steam generation. However, the copious quantities of resources that are below $70^{\circ} \mathrm{C}$ are usually discounted by the industry as too difficult to capture and repurpose. However, it is proposed that an effective way to recover this low-grade waste heat, is upgrading it with heat pumps. This can allow for the recovery of waste-heat as an economically viable option as well as reduce overall greenhouse gas emissions. Geothermal heat pumps, which can provide a lift in temperature from 15 to $20^{\circ} \mathrm{C}$ to around $30-40^{\circ} \mathrm{C}$ can be effective for the recovery of 
waste heat within flooded abandoned mines for use in local space heating, such as in nearby homes or community centers. For operational sites, such as smelters, process cooling streams offer the most potential and chemical heat pumps are the more appropriate option as they can provide a temperature increase greater than $25^{\circ} \mathrm{C}$. The recovered heat becomes more suitable for displacing existing process stream heaters or to be used to replace fossil fuel fired boilers to supply space heating, thereby reducing both annual operating costs, as well as $\mathrm{CO}_{2}$ emissions.

\section{Conflict of interest}

None declared.

\section{Ethical statement}

Authors state that the research was conducted according to ethical standards.

\section{Funding body}

Funding has been provided by the Mitacs Accelerate program and the National Science and Research Council (NSERC).

\section{References}

[1] Huang F, Zheng J, Baleynaud JM, Lu J. Heat recovery potentials and technologies in industrial zones. Journal of the Energy Institute 2017;90:951-61. https://doi.org/10.1016/ j.joei.2016.07.012.

[2] Holmberg K, Kivikyto-Reponen P, Harkisaari P, Valtonen K, Erdemir A. Global energy consumption due to friction and wear in the mining industry. Tribology International 2017; 115:116-39. https://doi.org/10.1016/j.triboint.2017.05.010.

[3] Luo A, Fang H, Xia J, Lin B, jiang Y. Mapping potentials of low-grade industrial waste heat in Northern China. Res Conser Recycl 2017;125:335-48. https://doi.org/10.1016/ j.resconrec.2017.06.018.

[4] Natural Resources Canada. National energy use database. URL, http://oee.nrcan.gc.ca/corporate/statistics/neud/dpa/ showTable.cfm?type $=$ HB\&sector $=$ aaa \&juris $=$ ca\&rn $=3 \&$ page $=0$. [Accessed 9 April 2019].

[5] Miah JH, Griffiths A, McNeill R, Poonaji I, Martin R, Leiser A, Morse S, Yang A, Sadhukhan J. Maximising the recovery of low grade heat: An integrated heat integration framework incorporating heat pump intervention for simple and complex factories. Applied Energy 2015;160:172-84. https://doi.org/10.1016/j.apenergy.2015.09.032.

[6] Ross IM. Employing heat pumps to recover low grade industrial thermal resources for space heating and cooling. Sudbury, Canada: Laurentian University; 2016.

[7] Kermani M, Wallerand AS, Kantor ID, Maréchal F. Generic superstructure synthesis of organic Rankine cycles for waste heat recovery in industrial processes. Applied Energy 2018; 212:1203-25. https://doi.org/10.1016/j.apenergy.2017.12.094.

[8] van de Bor DM, Infante Ferreira CA, Kiss AA. Low grade waste heat recovery using heat pumps and power cycles. Energy 2015;89:864-73. https://doi.org/10.1016/ j.energy.2015.06.030.
[9] Bluhm S. Improving mine ventilation electricity consumption. URL, https://www.miningreview.com/improving-mineventilation-electricity-consumption/. [Accessed 14 August 2018].

[10] Singh R. Quality requirements of iron ore for iron production. In: Singh R, editor. Applied welding engineering. Butterworth-Heinemann; 2016. p. 3-5. https://doi.org/10.1016/ B978-0-12-804176-5.00001-3.

[11] Norgate T, Haque N. Energy and greenhouse gas impacts of mining and mineral processing operations. J Clean Prod 2010;18:266-74. https://doi.org/10.1016/j.jclepro.2009.09.020.

[12] Department of the Environment and Energy. Ways to save mining. Energy efficiency exchange. URL, https://www.eex. gov.au/opportunities-mining. [Accessed 8 September 2018].

[13] Johnson I, Choate B, Dillich S. Waste heat recovery: Opportunities and challenges. TMS annual meeting and exhibition, TMS annual meeting. Minerals, Metals and Materials Society; 2008. p. 47-52.

[14] O'Rielly K, Jeswiet J. Improving industrial energy efficiency through the implementation of waste heat recovery systems. Trans Can Soci Mech Eng 2015;39:12.

[15] Zhang J, Zhang H-H, He Y-L, Tao W-Q. A comprehensive review on advances and applications of industrial heat pumps based on the practices in China. Applied Energy 2016;178:800-25. j.apenergy.2016.06.049.

[16] Bao H, Ma Z, Roskilly AP. Integrated chemisorption cycles for ultra-low grade heat recovery and thermo-electric energy storage and exploitation. Applied Energy 2016;164:228-36. https://doi.org/10.1016/j.apenergy.2015.11.052.

[17] Guo J, Huai X, Xu M. Thermodynamic analysis of an isopropanol-acetone-hydrogen chemical heat pump. International Journal of Energy Research 2015;39:140-6. https:// doi.org/10.1002/er.3237.

[18] Obracaj D, Sas S. Possibilities of using energy recovery in underground mines. EDP Sciences 2018;29. https://doi.org/ 10.1051/e3sconf/20182900012.

[19] Xiong H, Liu H, Li Y, Gao L. Design of air thermal recovery experiment device and analysis of thermal efficiency. In: 9 th international symposium on heating, ventilation and air conditioning, ISHVAC joint with the 3rd international conference on building energy and environment, COBEE, procedia engineering. Elsevier Ltd; 2015. p. 1567-73. https:// doi.org/10.1016/j.proeng.2015.09.179.

[20] Holmlund K. Heat recovery solutions for mine ventilation systems. Karlstad, Sweden: Karlstad University; 2015.

[21] Sbarba HD, Fytas K, Paraszczak J. Economics of exhaust air heat recovery systems for mine ventilation. Int J Min Reclam Environ 2012;26:185-98. https://doi.org/10.1080/ 17480930.2012.710085.

[22] Bailey MT, Gandy CJ, Watson IA, Wyatt LM, Jarvis AP. Heat recovery potential of mine water treatment systems in Great Britain. International Journal of Coal Geology 2016;164: 77-84. https://doi.org/10.1016/j.coal.2016.03.007.

[23] Hall A, Scott JA, Shang H. Geothermal energy recovery from underground mines. Renewable and Sustainable Energy Reviews 2011;15:916-24. https://doi.org/10.1016/ j.rser.2010.11.007.

[24] Farr G, Sadasivam S, Manju, Watson, Ian A, Thomas, Hywel R, Tucker D. Low enthalpy heat recovery potential from coal mine discharges in the South Wales Coalfield. International Journal of Coal Geology 2016;164:92-103. https://doi.org/10.1016/j.coal.2016.05.008.

[25] Nardin G, Ciotti G, Dal Magro F, Meneghetti A, Simeoni P. Waste heat recovery in the steel industry: Better internal use or external integration?. XXIII summer school industrial systems engineering. URL, https://www.summerschool-aidi. it/section.php?id=29; 2018.

[26] Keplinger T, Haider M, Steinparzer T, Patrejko A, Trunner P, Haselgrubler M. Dynamic simulation of an electric arc furnace waste heat recovery system for steam production. Applied Thermal Engineering 2018a;135:188-96. https:// doi.org/10.1016/j.applthermaleng.2018.02.060. 
[27] Keplinger T, Haider M, Steinparzer T, Trunner P, Patrejko A, Haselgrubler M. Modeling, simulation, and validation with measurements of a heat recovery hot gas cooling line for electric arc furnaces. Steel Research International 2018b;89. https://doi.org/10.1002/srin.201800009.

[28] Loken M. Recovery of waste heat from pyrometallurgical facilites for use in microalgae production. Sudbury, Ontario: Laurentian University; 2013.

[29] Lecompte S, Oyewunmi OA, Markides CN, Lazova M, Kaya A, Van Den Broek M, De Paepe M. Case study of an organic Rankine cycle (ORC) for waste heat recovery from an electric arc furnace (EAF). Energies 2017;10. https://doi.org/ 10.3390/en10050649.

[30] Laamanen CA, Shang H, Ross GM, Scott JA. A model for utilizing industrial off-gas to support microalgae cultivation for biodiesel in cold climates. Energy Convers Man 2014;88: 476-83. https://doi.org/10.1016/j.enconman.2014.08.047.

[31] Warhurst A, Noronha ML. Environmental policy in mining: Corporate strategy and planning. CRC Press; 1999.

[32] Xie D, Pan Y, Flann R, Washington B, Sanetsis S, Donnelley J. Heat recovery from slag through dry granulation. CSRP Conference 2007:29-30.

[33] Zhang H, Wang H, Zhu X, Qiu Y-J, Li K, Chen R, Liao Q. A review of waste heat recovery technologies towards molten slag in steel industry. Applied Energy 2013;112: 956-66. https://doi.org/10.1016/j.apenergy.2013.02.019.

[34] Rodd L, Koehler T, Voermann N. Economics of slag heat recovery from ferronickel slags, Vol. 15. Canadian Institute of Mining, Metallurgy and Petroleum; 2010.

[35] Motz H, Ehrenberg A, Mudersbach D. Dry solidification with heat recovery of ferrous slag. Min Process Extrac Metall 2015; 124:67-75. https://doi.org/10.1179/1743285514Y.0000000082.

[36] Institute for Industrial Productivity. Industrial efficiency technology \& measures. URL, http://ietd.iipnetwork.org/ content/heat-recovery-cooling-water. [Accessed 12 October 2018].

[37] Jeswiet J, Szekeres A. Energy consumption in mining comminution. Procedia CIRP 2016;48:140-5. https://doi.org/ 10.1016/j.procir.2016.03.250.

[38] Ninikas K, Hytiris N, Emmanuel R, Aaen B, McMillan S. A renewable heat solution for water ingress in the Glasgow subway tunnel system. In: Presented at the energy and sustainability 2014. Malaysia: Kuala Lumpur; 2014. p. 161-71. https://doi.org/10.2495/ESUS140141.

[39] Ogura H. Effects of heat exchange condition on hot air production by a chemical heat pump dryer using $\mathrm{CaO} / \mathrm{H} 2 \mathrm{O} /$ $\mathrm{Ca}(\mathrm{OH}) 2$ reaction. Chem Eng J 2002;86:3-10. https://doi.org/ 10.1016/S1385-8947(01)00265-0.

[40] Wendt DS, Sabharwall P, Utgikar V. Technologies for upgrading light water reactor outlet temperature. In: Volume 1: Heat transfer in energy systems; thermophysical properties; theory and fundamental research in heat transfer. Presented at the ASME 2013 heat transfer summer conference collocated with the ASME 2013 7th international conference on energy sustainability and the ASME 2013 11th international conference on fuel cell science, engineering and technology. Minneapolis, Minnesota, USA: ASME; 2013. https://doi.org/10.1115/HT2013-17122. V001T01A013.

[41] Loredo C, Roqueñí N, Ordóñez A. Modelling flow and heat transfer in flooded mines for geothermal energy use: A review. Int J Coal Geology 2016;164:115-22. https://doi.org/ 10.1016/j.coal.2016.04.013.

[42] Stantec. Mine water treatment. URL, https://www.stantec. com/en/services/mine-water-treatment. [Accessed 28 November 2018].

[43] SKRC. Mine water as a renewable energy resource. URL, http://skrconline.net/content/images/stories/documents/ mine_water_renewable_ener gy_guide.pdf. [Accessed 28 November 2018].

[44] Hiddes L, Stefens J, Verhoeven R, Dix M, Eijdems H. The Netherlands. In: Smart energy regions. The Welsh school of architecture, cardiff, UK; 2014. p. 169-285.
[45] MacAskill D, Power C. Researching the geothermal potential of the former springhill mine. Cape Breton: Verschuren Centre for Sustainability in Energy and the Environment; 2015.

[46] Jessop A, Macdonald K, J, Spence H. Clean energy from abandoned mines at springhill, Nova Scotia. Energy Sources 1995;17. https://doi.org/10.1080/00908319508946072.

[47] Koufos K. Assessing the potential to implement open loop geothermal systems in Canadian underground mines. Montreal: McGill University; 2011.

[48] Peralta Ramos E, Breede K, Falcone G. Geothermal heat recovery from abandoned mines: A systematic review of projects implemented worldwide and a methodology for screening new projects. Environ Earth Sci 2015;73:6783-95. https://doi.org/10.1007/s12665-015-4285-y.

[49] Banks D, Skarphagen H, Wiltshire R, Jessop C. Heat pumps as a tool for energy recovery from mining wastes. Geological Society - Special Publications 2004;236:499-513.

[50] Ghoreishi-Madiseh SA, Kuyuk AF. A techno-economic model for application of geothermal heat pump systems. Energy Procedia. Proceedings of the 9th International Conference on Applied Energy 2017;142:2611-6. https://doi.org/ 10.1016/j.egypro.2017.12.200.

[51] Thompson A. Geothermal development in Canada: Country update. Can Geother Ene Ass 2010;3.

[52] Ghomshei M. Geothermal energy from con mine for heating the city of Yellowknife, nwt: A concept study. Vancouver: The University of British Columbia; 2007.

[53] Gandt K, Meier T, Echterhof T, Pfeifer H. Heat recovery from EAF off-gas for steam generation: Analytical exergy study of a sample EAF batch. Ironmaking and Steelmaking 2016;43: 581-7. https://doi.org/10.1080/03019233.2016.1155812.

[54] Kolagar AH, Meier T, Echterhof T, Pfeifer H. Modeling of the off-gas cooling system for an electric arc furnace and evaluation of the heat recovery potential. Chemie Ingenieur Technik 2016;88:1463-73. https://doi.org/10.1002/ cite.201600009.

[55] Institute for Industrial Productivity. electric arc furnace. URL, http://ietd.iipnetwork.org/content/electric-arc-furnace. [Accessed 21 September 2018].

[56] Bramfoot S, Dixon J, Martin JR, Robertson AD. Design OF waste heat boilers for the recovery OF energy from arc furnace waste gases. Energy conservation in industry combustion, heat recovery and rankine cycle machines, proceedings of the contractors' meetings., commission of the European communities, (report) EUR. D. . Reidel Publ Co; 1983. p. 131-41.

[57] Thekdi A, Nimbalkar S, Keiser J, Storey J. Preliminary results from electric arc furnace off-gas enthalpy modeling. In: Presented at the the iron \& steel technology conference and exposition, oak ridge national lab. (ORNL), oak ridge, TN (United States), United States; 2015. p. 15.

[58] Slade R, Bauen A. Micro-algae cultivation for biofuels: Cost, energy balance, environmental impacts and future prospects. Biomass and Bioenergy 2013;53:29-38. https://doi.org/ 10.1016/j.biombioe.2012.12.019.

[59] Cherubini F, Bird ND, Cowie A, Jungmeier G, Schlamadinger B, Woess-Gallasch S. Energy - and greenhouse gas-based LCA of biofuel and bioenergy systems: Key issues, ranges and recommendations. Resources, Conservation and Recycling 2009;53:434-47. https://doi.org/10.1016/ j.resconrec.2009.03.013.

[60] van Esbroeck E. Temperature control of microalgae cultivation under variable conditions. Wageningen, Netherlands: Wageningen University \& Research; 2018.

[61] Rycroft M. Heat recovery from slag improves energy efficiency of furnaces. Energize 2014;3.

[62] Chen C, Habert G, Bouzidi Y, Jullien A, Ventura A. LCA allocation procedure used as an incitative method for waste recycling: An application to mineral additions in concrete. Resources, Conservation and Recycling 2010;54:1231-40. https://doi.org/10.1016/j.resconrec.2010.04.001. 
[63] Das B, Prakash S, Reddy PSR, Misra VN. An overview of utilization of slag and sludge from steel industries. Resources, Conservation and Recycling 2007;50:40-57. https:// doi.org/10.1016/j.resconrec.2006.05.008.

[64] Zhu X, Ding B, Wang H, He X-Y, Tan Y, Liao Q. Numerical study on solidification behaviors of a molten slag droplet in the centrifugal granulation and heat recovery system. Applied Thermal Engineering 2018;130:1033-43. https:// doi.org/10.1016/j.applthermaleng.2017.11.080.

[65] Allen B. Ferrous slag market worth \$28 billion in 2020. Smithers Group; 2018. URL, https://www.smitherspira.com/ news/2010/march/global-ferrous-slag-market-growth-to2020. [Accessed 12 December 2018].

[66] Zuo Z, Yu Q, Xie H, Liu S, Liu J, Yang F, Qin Q. Thermodynamic analysis on molten slag waste heat cascade recovery method (MS-WHCR). J Ther Anal Calorim 2018;134:2171-81. https://doi.org/10.1007/s10973-018-7421-6.

[67] Duan W, Yu Q, Wang Z, Liu J, Qin Q. Life cycle and economic assessment of multi-stage blast furnace slag waste heat recovery system. Energy 2018;142:486-95. https:// doi.org/10.1016/j.energy.2017.10.048.

[68] van Laar R, Dupon E, Barel J, Kamerling M. Blast furnace slag granulation plant technology. millennium steel 4. 2014.

[69] McDonald IJ, Werner A. Dry slag granulation with heat recovery. In: Anais Dos Seminários de Redução, Minério de Ferro e Aglomeração. Presented at the $45^{\circ}$ Redução $/ 16^{\circ}$ Minério de Ferro $/ 3^{\circ}$ Aglomeração. Rio de Janeiro: Editora Blucher; 2017. p. 286-95. https://doi.org/10.5151/2594-357X26526.
[70] Yu P, Wang S, Li Y, Xu G. A review of granulation process for blast furnace slag. In: Arumugham AJ, Ulkhaq MM, Kocisko M, Goyal RK, Yusmawiza WA, Qiu X, editors. Presented at the the 3rd international conference on industrial engineering and applications; 2016. p. 4. https://doi.org/ $10.1051 /$ matecconf/20166806007.

[71] Bisio G. Energy recovery from molten slag and exploitation of the recovered energy. Energy 1997;22:501-9. https:// doi.org/10.1016/S0360-5442(96)00149-1.

[72] Sun Y, Zhang Z, Liu L, Wang X. Heat recovery from high temperature slags: A review of chemical methods. Energies 2015;8:1917-35. https://doi.org/10.3390/en8031917.

[73] Shigaki N, Tobo H, Ozawa S, Ta Y, Hagiwara K. Heat recovery process from packed bed of hot slag plates. ISIJ International 2015;55:2258-65. https://doi.org/10.2355/ isijinternational.ISIJINT-2015-169.

[74] Duan W, Yu Q, Zuo Z, Qin Q, Li P, Liu J. The technological calculation for synergistic system of BF slag waste heat recovery and carbon resources reduction. Energy Conversion and Management 2014;87:185-90. https://doi.org/10.1016/ j.enconman.2014.07.029.

[75] Sun Y, Zhang Z, Liu L, Wang X. Multi-stage control of waste heat recovery from high temperature slags based on time temperature transformation curves. Energies 2014;2014: 1673-84. https://doi.org/10.3390/en7031673.

[76] Kahraman A, Çelebi A. Investigation of the performance of a heat pump using waste water as a heat source. Energies 2009; 2:697-713. https://doi.org/10.3390/en20300697. 